\title{
Segmenting Landowners of Shandong, China Based on Their Attitudes towards Forest Certification
}

\author{
Nana Tian ${ }^{1, *}\left(\mathbb{D}\right.$, Fadian Lu ${ }^{2}$, Omkar Joshi ${ }^{3}$ (i) and Neelam C. Poudyal ${ }^{4}$ \\ 1 Texas A\&M Forest Service, 200 Technology Way, Suite 1281, College Station, TX 77845, USA \\ 2 Department of Forestry, Shandong Agricultural University, Daizong St. 61, Taian 271018, China; \\ lfd@sdau.edu.cn \\ 3 Department of Natural Resource Ecology and Management, Oklahoma State University, 008C Ag Hall, \\ Stillwater, OK 74078, USA; omkar.joshi@okstate.edu \\ 4 Department of Forestry, Wildlife \& Fisheries, University of Tennessee, 274 Plant Science Bldg. Knoxville, \\ TN 37996, USA; npoudyal@utk.edu \\ * Correspondence: nana.tian@tfs.tamu.edu; Tel.: +1-979-458-6634
}

Received: 2 May 2018; Accepted: 13 June 2018; Published: 18 June 2018

\begin{abstract}
Forest certification is considered a viable market-based policy instrument to promote forest sustainability. It has an important role of play in meeting the objective of modern forestry development in China, which is to sustain ecological and environmental benefits of forests. To understand differences in attitudes, opinions, and interests in forest certification, this study segmented respondents of a landowner's survey in Shandong, China based on their level of interest in participating in forest certification under different program requirements. Multivariate cluster analysis revealed three distinct groups: likely-, potential-, and unlikely-landowners. We further examined the heterogeneity of these groups in terms of their demographics, ownership characteristics, management objectives, and perceived benefits and challenges of adopting forest certification. The results suggested the necessity of differentiating landowners in formulating and designing specific motivation-based incentives and tailoring outreach efforts and communication strategies to improve their interests in forest certification. Findings will be useful and interesting to forest policymakers interested in promoting forest certification among landowners in China and other countries facing similar circumstances.
\end{abstract}

Keywords: forest certification; market segmentation; cluster analysis; motivation schemes

\section{Introduction}

Forest certification is an accreditation process during which landowners voluntarily seek a third independent party to evaluate their timber management practices based on a range of predetermined standards and then assess whether forests are managed ensuring environmental and socio-economical sustainability [1]. Primarily, forest certification was designed to reduce deforestation and promote the management of tropical forests [2-5], but it has expanded as a tool to achieve sustainable forest management all over the world. China, a country with 208 million hectares of forest [6], has a huge potential market for forest certification. In addition, China has a high afforestation rate; for instance, the forest coverage has increased from $12 \%$ to about $21 \%$ in 30 years (from 1983 to 2013) and the current goal is to reach $23 \%$ of the total area by 2020 [7].

In the history of China, urbanization and industrialization caused overharvesting and the illegal logging of natural forests for timber, iron, and steel production, which led to the severe decline of biodiversity and degradation of the environment [8,9]. For example, over-logging was believed to be one of the primary reasons for the catastrophic floods of 1998 of the Yangtze River [10,11], 
which triggered Chinese officials to take actions (e.g., enact policies to sustain forest management) to combat deforestation. Meanwhile, both economic globalization and the growing realization of the importance of forests in improving environmental quality drove the necessity of promoting forest management. Therefore, forest certification as a market-based strategy received political and policy support from government officials. Currently, existing forest certification programs in China include the Forest Stewardship Council (FSC), Programme for the Endorsement of Forest Certification schemes (PEFC), and China Forest Certification Council (CFCC), which was endorsed by the PEFC. Those programs envision sustainable forest management practices to respond to economic, environmental, and social needs of the landowners.

These forest certification programs, unfortunately, had a low familiarization among landowners; thus, designing motivation mechanisms and outreach services to improve their knowledge and interests in forest certification became a challenge. Considering the diversity of landowners across the world in terms of their management objectives and demographic attributes [12-15], a one size fits all formula becomes practically impossible to implement anywhere and more so within the convoluted social structure of China. Therefore, segmentation-based attitudes towards forest certification are necessary to identify unique clientele of landowners, so as to make outreach services effective.

Recently, a number of studies have been published using segmentation techniques to study landowners on a global scale. Many studies (e.g., [16-23] segmented landowners based on their ownership objectives and yielded different owner groups. For example, Majumdar et al. [22], based on their management objectives, grouped family landowners in the southern United States into multiple-objective, non-timber, and timber landowners. Likewise, numerous studies have also examined the different characteristics of landowners regarding the implementation of forest conservation programs. For example, Surendra et al. [24] classified landowners into four groups according to their information-seeking behavior. The authors found that targeting landowners based on their ownership objectives was useful to stimulate forest management. Likewise, Salmon et al. [25] employed a benefit-based audience segmentation technique to identify the education needs for nonindustrial private forest landowners (NIPF). Similarly, Butler et al. [26] segmented landowners into four groups based on their attitudes to a conservation program and implied that segmentation can improve the efficiency of program implementation by developing effective and efficient outreach policies and services to landowners. Herbohn et al. [27] grouped landowners according to their attitudes to farm forestry in eastern Australia and concluded that understanding the constraints for each segmentation was helpful for taking appropriate actions. Hujala et al. [28] grouped landowners into trusting realizers, active learners, and independent managers using their decision-making modes and suggested differentiating weighted decision support services for each clientele. In short, review of the existing literature suggests that numerous studies have segmented forest landowners in western countries. However, they cannot be generalized to design and develop outreach programs in China-a country with a distinct ideological, political, geographical, and socio-economical identity.

In addition, several studies have examined the effectiveness of forest certification globally. For example, studies of the World Wildlife Fund European Forest Programme (WWF) [29] found that the conservation status and biodiversity levels were improved in the certified forests in central European countries. Similarly, the Federation of Nordic Forest Owner's Organisations [30] examined the certification's effectiveness and benefits in Finland, Sweden, and Norway and stated that forest certification has enhanced the sustainable management level and particularly improved the environmental protection. Meanwhile, this study also claimed that the recognition of better environmental figures might extend market access for Nordic timber and wood products [30]. Moreover, Rickenbach and Overdevest [31] examined the certification holders' expectations of forest certification in the U.S. and found that better recognition of responsible forest practice is the most satisfied certification benefit. Forest certification is likely to have a broader impact on forest and timber markets; for instance, Busby et al. [32] reported that price premium for certified timber would encourage the adoption of forest certification among private landowners in Oregon. The key 
financial benefit of forest certification is market access. In summary, the benefits of forest certification were grouped into conventional economic, social, and environmental components of sustainable development $[31,33]$. In addition to those perceived benefits associated with forest certification, there are also direct and indirect expenses related to certification adoption. Clearly, the most important barrier/disadvantage of certification is the certification cost. For example, Bansel [34] and Perera et al. [35] investigated private landowners in the US and both concluded that the major concern to certification is the high certification cost. Also, a lack of price premium and inadequate markets for certified timber were other constraints related to the certification program [36]. Other barriers to the certification program included the requirement of following a management plan and meeting certification standards [1,37]. Possible drawbacks associated with certification steps were on-site field inspection and increased paperwork within the certification process [37].

Overall, how landowners manage their forests or whether they certify their forests to ensure sustainable management practices is an issue of significant public interest. To meet the goals of sustainable forest management and increase the sound forest stewardship, policy makers need to have a deeper and better understanding of landowners before developing effective outreach, policies, and service programs. Given that landowners have varying perceptions of forest certification and differing levels of interests in its participation, it is critical to understand landowner typologies to develop a well-focused communication program. Therefore, to improve the health and productivity of forests and consequently to meet the sustainable management goal, the main objective of this study is to understand the characteristics of different landowners and to identify outreach approaches that can help motivate passive landowners to participate in forest certification programs. Specifically, the objectives are to: (1) segment landowners based on their interest level in forest certification; (2) understand the demographics, forestland characteristics, and ownership characteristics of different landowner groups; (3) obtain the differences among landowner groups concerning their familiarity with forest certification and perceptions for potential benefits and drawbacks of this program; and (4) suggest outreach and service programs to enhance landowners' interest in certification.

\section{Methodologies}

\subsection{Data Collection}

The survey was designed after a comprehensive review of the literature regarding landowners' willingness to adopt forest certification and the associated factors that potentially influence their management decisions. We developed 27 questions in this survey and they were grouped into: (1) ownership characteristics (e.g., tenure, ownership size etc.); (2) landowners' motivations for owning forestland; (3) landowners' management objectives; 4) landowners' willingness to adopt forest certification under various program requirements; (5) landowners' perceptions of possible benefits and drawbacks correlated with forest certification; and (6) socio-demographic (e.g., age, gender etc.). Meanwhile, landowners' interest level in forest certification under various program designs was measured using a five-point Likert scale ( 1 = Very unlikely, $2=$ Unlikely, $3=$ Neutral, $4=$ Likely, and $5=$ Very likely); similarly, their agreement level for perceived benefits and drawbacks of forest certification was also measured using the Likert scale ( $1=$ Strongly disagree, $2=$ Disagree, $3=$ Neutral, $4=$ Agree, 5 = Strongly agree).

This survey was developed in both English and Mandarin and both of them were approved by the Institutional Review Board at the University of Tennessee, Knoxville in the United States. The survey was administered in different cities (Taian, Jinan, Linyi, Liaocheng, Jining, and Weifang) of Shandong, China in the summer of 2016 and the Mandarin version was mainly used in the field. The Shandong province of China has a population of about 97 million people (Shandong Statistical Yearbook, 2015). This province has a large forested area (approximately 2.55 million hectares) and forest coverage is around $16.73 \%$, which provides a potential market for forest certification. 
We firstly visited the local forestry officials after getting to each city and collected information regarding who has forestland and how we could approach them etc. A convenient landowner sample was employed according to the provided list by the local forestry officials and with their assistance, we personally approached those randomly selected landowners, who were later requested to fill out the survey. For those who were not familiar at all with forest certification, we offered a brief informative instruction accompanied with the survey. In the latter case, landowners were requested to provide their response to the questions that required minimal understanding of forest certification. In total, we approached 557 landowners, out of which 50 did not finish all the questions included in the survey. Therefore, we used 507 completed surveys for the remainder of this analysis, yielding a response rate of $91 \%$. Since the response rate was very high (91\%), we do not think non-response bias was a concern for this survey.

\subsection{Cluster Analysis}

Market segmentation is a widely used approach in the marketing field to separate a heterogeneous population (e.g., landowners) into homogeneous subgroups based on their common/shared characteristics [24]. The intent of market segmentation is to identify subgroups of customers according to a series of demographic and behavior variables and then incorporate this information into outreach and policy development. Multivariate regressions techniques such as cluster analysis have been commonly applied in market segmentation [12,38-40]. Among others, $k$-means cluster analysis with Euclidian distance is a widely used algorithm for segmenting audiences [38,40]. In principle, the clusters should capture the structure of the data, meaning that the objects within same group share the common characteristics, whereas those within different groups have different characteristics. Hence, the objective of $k$-means cluster analysis is to minimize within group differences but maximize between group differences [41] (Equation (1)).

$$
J(V)=\sum_{i=1}^{c} \sum_{j=1}^{c_{i}}\left(\left\|x_{i}-v_{j}\right\|\right)^{2}
$$

where $\left(\left\|x_{i}-v_{j}\right\|\right)$ is the distance between $x_{i}$ and $v_{j} ; c_{i}$ is the number of data points in the $i^{\text {th }}$ cluster; and $c$ is the number of cluster centers.

A $k$-means cluster analysis was employed in this study to segment the landowners based on their willingness to participate in forest certification under different program designs and conditions. As is typical in any $k$-means clustering, two-, three-, and four-cluster segments were tried. The three-cluster solution (Table 1) was chosen as the best fit to the data and yielded the clearest divisions among clusters comparing the results from other solutions. Then, analysis of variance (ANOVA) was used to test for differences in subsequent clusters (0.05-significance level was used for all tests). Objective information included demographics and ownership characteristics, as well as their perceptions of perceived benefits and challenges associated with forest certification that further described the clusters/segmented landowners. 
Table 1. Respondents' interest level in forest certification under various program designs in three landowner groups.

\begin{tabular}{|c|c|c|c|c|}
\hline & & Cluster Membership & & \\
\hline Variables & $\begin{array}{l}\text { Likely Landowners } \\
\qquad(n=120)\end{array}$ & $\begin{array}{l}\text { Potential Landowners } \\
\qquad(n=233)\end{array}$ & $\begin{array}{l}\text { Unlikely Landowners } \\
\qquad(n=154)\end{array}$ & $\begin{array}{c}\text { F and } \\
p \text {-value }\end{array}$ \\
\hline \multicolumn{5}{|l|}{ If certifying organization were: } \\
\hline Products industry association & 4 & 3 & 3 & $\begin{array}{c}\mathrm{F}=57.9973 \\
(p<0.001)\end{array}$ \\
\hline Forest landowner association & 4 & 3 & 3 & $\begin{aligned} \mathrm{F} & =45.85 \\
(p & <0.001)\end{aligned}$ \\
\hline Pay all of certification cost & 3 & 2 & 2 & $\begin{aligned} \mathrm{F} & =67.57 \\
(p & <0.001)\end{aligned}$ \\
\hline $\begin{array}{l}\text { Certification results not } \\
\text { available to the public }\end{array}$ & 4 & 3 & 2 & $\begin{array}{l}\mathrm{F}=73.65 \\
(p<0.001)\end{array}$ \\
\hline Management plan required & 4 & 4 & 3 & $\begin{aligned} \mathrm{F} & =63.97 \\
(p & <0.001)\end{aligned}$ \\
\hline No management plan required & 3 & 2 & 2 & $\begin{array}{l}\mathrm{F}=124.01 \\
(p<0.001)\end{array}$ \\
\hline $\begin{array}{l}\text { Required to use professional } \\
\text { forester }\end{array}$ & 4 & 4 & 2 & $\begin{array}{l}\mathrm{F}=64.34 \\
(p<0.001)\end{array}$ \\
\hline $\begin{array}{l}\text { Not required to use professional } \\
\text { forester }\end{array}$ & 3 & 2 & 2 & $\begin{array}{l}\mathrm{F}=195.37 \\
(p<0.001)\end{array}$ \\
\hline Required to use trained loggers & 4 & 4 & 2 & $\begin{aligned} \mathrm{F} & =65.46 \\
(p & <0.001)\end{aligned}$ \\
\hline $\begin{array}{l}\text { Not required to use trained } \\
\text { loggers }\end{array}$ & 4 & 4 & 2 & $\begin{array}{l}\mathrm{F}=164.93 \\
(p<0.001)\end{array}$ \\
\hline $\begin{array}{l}\text { May receive higher price for } \\
\text { stumpage }\end{array}$ & 5 & 4 & 3 & $\begin{aligned} \mathrm{F} & =14.00 \\
(p & <0.001)\end{aligned}$ \\
\hline $\begin{array}{l}\text { May receive the same price for } \\
\text { stumpage }\end{array}$ & 3 & 3 & 2 & $\begin{array}{l}\mathrm{F}=155.86 \\
(p<0.001)\end{array}$ \\
\hline Preference for wood in market & 5 & 4 & 3 & $\begin{aligned} \mathrm{F} & =14.69 \\
(p & <0.001)\end{aligned}$ \\
\hline $\begin{array}{l}\text { No preference for product in } \\
\text { market }\end{array}$ & 3 & 3 & 2 & $\begin{array}{l}\mathrm{F}=136.76 \\
(p<0.001)\end{array}$ \\
\hline
\end{tabular}

Note: 1 = very Unlikely; 2 = Unlikely; 3 = Unsure; 4 = Likely; 5 = Very Likely.

\section{Results}

Among the 507 completed surveys, $71 \%$ were male and on average, the tenure was 22 years. Regarding ownership size, $47 \%$ of the respondents owned forestland of $10 \sim 100$ hectares, $25 \%$ had greater than 100 hectares, and 27\% had less than 10 hectares. Approximately 50\% of the respondents reported high school education or less being their highest educational attainment. The percentage of landowners with vocational training and college education was equal at $25 \%$. About $34 \%$ of the respondents had an annual income greater than RMB 50,000, and 50\% had an income between RMB 20,000 and 50,000. Almost half (49\%) of the respondents were living in rural areas, whereas $47 \%$ were inhabitants of the county communities.

\subsection{Characteristics of Landowners Group}

The requisite survey data were analyzed using three audience segments resulting from cluster analysis. Respondents in the first group $(n=120)$ are likely landowners participating in forest certification under all program designs. Respondents in the second cluster $(n=233)$ were potential landowners and their concerns were the certification cost and the requirement of a management plan in managing their forestlands. Respondents in the third group $(n=154)$ were unlikely landowners, 
whose attitudes to forest certification were lower than neutral under almost all different program designs. We examined the socio-demographics, landowner motivation for owning forestlands, and forestland characteristics of these three subgroups to identify the typological differences. It was anticipated that study results could be tailored with the outreach programs that could help encourage landowners for forest certification as well as to explore other constraints. Our results suggest that landowners in those three subgroups did not differ significantly in terms of their age (Table 2). However, there were some distinctions among segments in terms of gender, education, and income. In addition, significant differences were found for forestland and ownership characteristics and motivations among the audience groups (Tables 3 and 4).

Table 2. Demographics by landowners group.

\begin{tabular}{|c|c|c|c|}
\hline & Likely Landowners & Potential Landowners & Unlikely Landowners \\
\hline \multicolumn{4}{|l|}{ Gender ** } \\
\hline Male (\%) & 76 & 75 & 57 \\
\hline Female (\%) & $24^{\mathrm{a}}$ & $25^{\mathrm{a}}$ & $43^{b}$ \\
\hline \multicolumn{4}{|l|}{ Education ** } \\
\hline Did not complete high school (\%) & $5^{a}$ & $13^{\mathrm{a}}$ & $31^{\mathrm{b}}$ \\
\hline Bachelors or higher $(\%)$ & $47^{\mathrm{a}}$ & $33^{a b}$ & $21^{b}$ \\
\hline \multicolumn{4}{|l|}{ Income $^{* *}$} \\
\hline Less than RMB 20,000 (\%) & $8^{a}$ & $14^{\mathrm{a}}$ & $15^{\mathrm{a}}$ \\
\hline \multicolumn{4}{|l|}{ Employment Status * } \\
\hline Forester/loggers/miner (\%) & $14^{\mathrm{a}}$ & $8^{a}$ & $0^{a}$ \\
\hline Professional manager $(\%)$ & $29^{a}$ & $27^{\mathrm{a}}$ & $32^{\mathrm{a}}$ \\
\hline Government employee (\%) & $11^{\mathrm{a}}$ & $5^{a}$ & $5^{a}$ \\
\hline Farmer $(\%)$ & $26^{\mathrm{a}}$ & $45^{b}$ & $50^{b}$ \\
\hline Retired/businessman/others (\%) & $20^{\mathrm{a}}$ & $15^{\mathrm{a}}$ & $13^{\mathrm{a}}$ \\
\hline
\end{tabular}

Note: * significant at $5 \%$ level; ${ }^{* *}$ Significant at $1 \%$ level; ${ }^{\text {a, b }}$ means with different subscripts are statistically different.

Table 3. Forest ownership characteristics by landowners group.

\begin{tabular}{lccc}
\hline & Likely Landowners & Potential Landowners & Unlikely Landowners \\
\hline Average Ownership size *(hectares) & $166^{\mathrm{a}}$ & $148^{\mathrm{a}}$ & $89^{\mathrm{b}}$ \\
Tenure ** (year.) & $25^{\mathrm{a}}$ & $21^{\mathrm{ab}}$ & $16^{\mathrm{a}}$ \\
Having a management plan **(\%) & $46^{\mathrm{a}}$ & $30^{\mathrm{b}}$ & $23^{\mathrm{b}}$ \\
Poplar forest**(\%) & $46^{\mathrm{a}}$ & $30^{\mathrm{b}}$ & $24^{\mathrm{c}}$ \\
Arborvitae forest (\%) & $0.04^{\mathrm{a}}$ & $0.02^{\mathrm{a}}$ & $0^{\mathrm{a}}$ \\
\hline Forests location & & & $14^{\mathrm{b}}$ \\
\hline Rural area/village** (\%) & $39^{\mathrm{a}}$ & $39^{\mathrm{a}}$ & $62^{\mathrm{b}}$ \\
Town/county (\%) & $38^{\mathrm{a}}$ & $39^{\mathrm{a}}$ & $24^{\mathrm{a}}$ \\
\hline Metropolitan area or suburb area (\%) & $23^{\mathrm{a}}$ & $22^{\mathrm{a}}$ & \\
\hline
\end{tabular}

Note: ${ }^{*}$ significant at $5 \%$ level; ${ }^{* *}$ Significant at $1 \%$ level; ${ }^{a, b, c}$ means with different subscripts are statistically different. 
Table 4. Ownership motivations by landowners group.

\begin{tabular}{lccc}
\hline & Likely Landowners & Potential Landowners & Unlikely Landowners \\
\hline Motivations of owing forests $(\%)$ & & & \\
\hline Enjoy the scenery ** & $60^{\mathrm{a}}$ & $58^{\mathrm{a}}$ & $32^{\mathrm{b}}$ \\
Protect nature $^{* *}$ & $80^{\mathrm{a}}$ & $73^{\mathrm{a}} \mathrm{b}$ & $74^{\mathrm{b}}$ \\
For recreation $^{* *}$ & $67^{\mathrm{a}}$ & $53^{\mathrm{b}}$ & $45^{\mathrm{b}}$ \\
Timber production $^{* *}$ & $87^{\mathrm{a}}$ & $69^{\mathrm{b}}$ & $66^{\mathrm{b}}$ \\
Land investment $^{* *}$ & $62^{\mathrm{a}}$ & $68^{\mathrm{a}}$ & $84^{\mathrm{b}}$ \\
Part of farm & $52^{\mathrm{a}}$ & $45^{\mathrm{a}}$ & $65^{\mathrm{b}}$ \\
\hline
\end{tabular}

Note: ${ }^{* *}$ Significant at $1 \%$ level; ${ }^{\mathrm{a}, \mathrm{b}}$ means with different subscripts are statistically different.

Likely Landowners: This group scored higher on almost all the different certification parameters than the other two landowner groups. They were the group of environmentally benign landowners with a level of motivation such that even under the condition that the certified timber received the same price and had the same market preference with the timber that was not certified, they would still likely to have their forestland certified (Table 1). They were willing to participate in certification even if certifying organizations were not required to use trained loggers or certification results were not available to the public (Table 1). Therefore, we categorized them as likely landowners. The average age of landowners was around 37 years, $76 \%$ of them were male - the highest gender disproportion among all three segments. Almost half (47\%) of landowners in this group hold bachelor's degree or higher, which was higher than the other two groups. Regarding their annual household income, $44 \%$ of landowners had an annual income between RMB 50,000 and 75,000, which was higher than the other two groups. Referring to the occupation of the landowners, $11 \%$ of them were government employees, which again was higher than the other groups (Table 2). This segment had the highest acres (166 hectares) of ownership size and the average tenure was around 25 years. Almost half $(46 \%)$ of them had a written management plan and they owned a timber oriented poplar forest. With regard to the forestland location, 39\% of them were located in the rural/village area, 38\% were located in the town/county area, and $23 \%$ was nearby/in a suburb of the metropolitan (Table 3). Among the reasons for managing forests, $87 \%$ of landowners stated timber production (Table 4), which is significantly higher than the other two groups.

Potential Landowners: The members in this group were unlikely to have their forestlands certified, if they had to pay all the certification costs. In addition, they were willing to participate only if there was a requirement of having a written management plan, as well as the use of a professional forester (Table 1). While they were not willing to pay all of the certification costs, they did not require trained loggers as a pre-requisite (Table 1). We categorized this subgroup as potential landowners because their participation was contingent upon overcoming previously mentioned constraints. The average age of this group was 40 years, which was relatively higher than other groups (Table 2) and almost half were farmers (45\%) (Table 2). Majority landowners in this group had high school/vocational training, whereas only one-third had a university degree. Over half of the respondents (52\%) had a household income between RMB 20,000 and 50,000 (Table 2). On average, potential landowners owned about 148 hectares of forestland, which was much higher than the third group and slightly smaller than the likely group. The average tenure for this group was about 21 years (Table 3). Majority (70\%) landowners did not have a management plan and slightly more than one-fifth (22\%) of their total forestlands were located nearby the metropolitan area. Finally, nature protection (73\%) and timber production $(69 \%)$ were the two most important motivations for owning their forestland (Table 4).

Unlikely Landowners: This group scored relatively low $(\leqq 3)$ on all program requirements, and as such, we categorized them as unlikely landowners. For example, they were not willing to participate in a forest certification program even if certifying organizations were willing to pay all of the certification costs or they received a higher price for stumpage after certification (Table 1). The average age of 
the members was 37 years, which was slightly less than the second group of members. However, this group represented more than two-fifth of female landowners-the highest among all three categories. As a group, these landowners had the lowest percentage of educational attainment, which was at a statistically significant distance from the first group. Likewise, majority landowners in this group represented a lower income class, with $73 \%$ having a household income lower than RMB 50,000. Most of the respondents were farmers (50\%) or professional managers (33\%) with no representation of foresters/loggers/miners (Table 2). Landowners, on average, owned about 89 hectares of forestlands, which was significantly lower than the other two groups and the average tenure of 26 years was also the lowest among the groups (Table 3). Less than one-fourth (23\%) of the members had a written management plan and $62 \%$ of the forestlands were distributed in town/county areas-the highest among groups (Table 3). The most important reason for owning forests was for land investment $(84 \%)$.

\subsection{Familiarity with Forest Certification}

Segmented landowners showed a statistically different level of familiarity with forest certification (Figure 1). For example, in the likely landowners group, only $9 \%$ reported not being familiar at all with certification programs, which is distinctly lower than the other two groups ( $29 \%$ in the potential landowners group and $30 \%$ in the unlikely landowners group). On the contrary, the percentage of respondents who were somewhat familiar, moderately familiar, or extremely familiar with forest certification was as high as 59\% in likely landowners, whereas it was $47 \%$ in potential landowners and $24 \%$ among unlikely landowners. The number of respondents who said slightly familiar with forest certification was highest in unlikely landowners (46\%), while it was $33 \%$ and $24 \%$, respectively, in likely and potential landowners clusters.

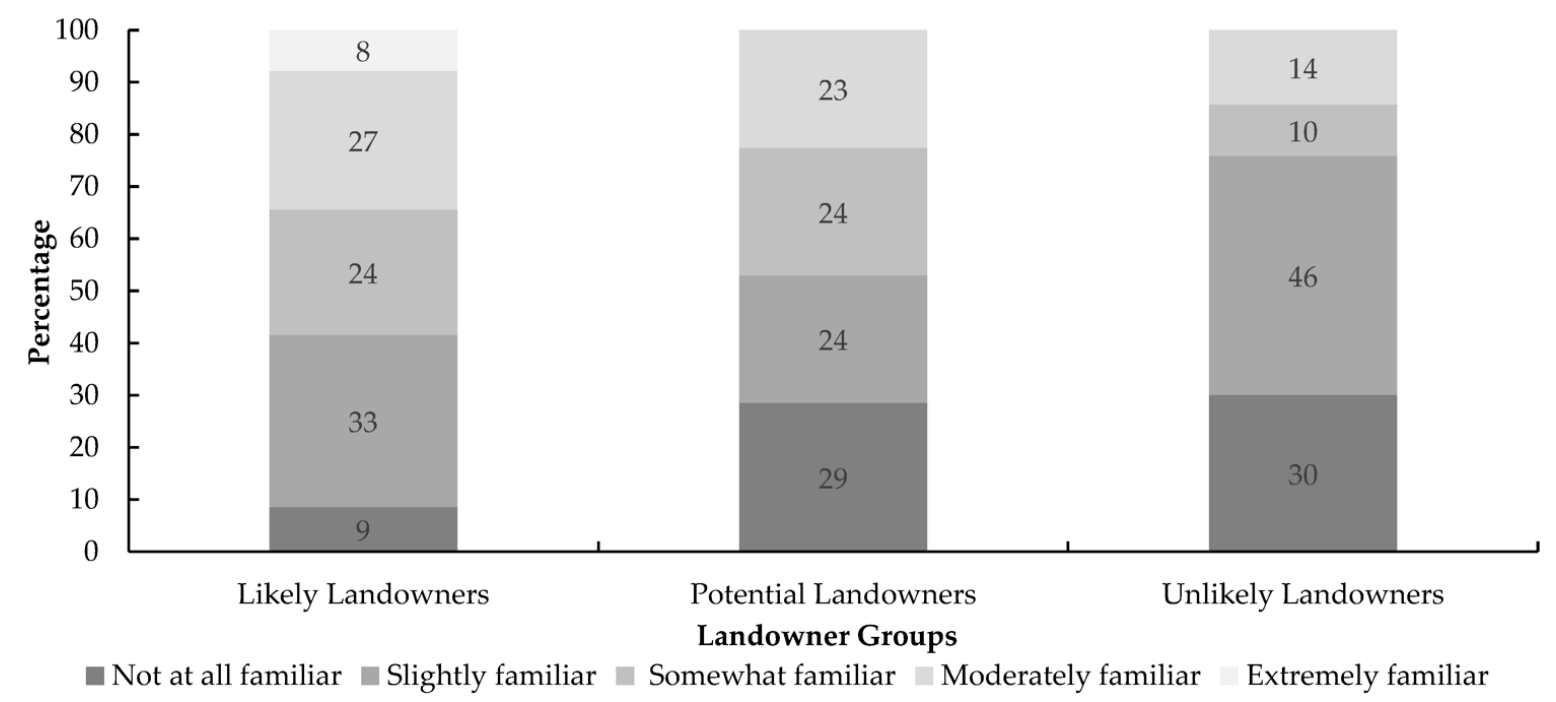

Figure 1. Landowners' familiarity with forest certification before reading the survey.

\subsection{Perceptions for Potential Benefits and Drawbacks with Forest Certification}

Respondents' perception of possible benefits and drawbacks related with forest certification is summarized in the Figures 2 and 3. The potential benefits of certification were composed of improved timber growth and health, expanded markets and price premium for harvested forest products, public recognition for working liable forestry, environmentally-responsible timber harvesting, and improved management practices. The group of likely landowners rated a high value $(>4)$ for all benefits except for expanded markets for harvested forest products $(=3.9)$, which was slightly lower than other benefits. The only statistically significant difference between likely landowners 
and potential landowners was found for their public recognition for practicing good forestry (Figure 2). Comparing potential landowners and unlikely landowners, there was a significant difference concerning perceptions, with attributes such as: increased timber growth and health, expanded markets for harvested forest products, and price premium for harvested forest products (Figure 2). Comparing the likely and unlikely landowner groups, there was a common perception for better management practices. For the other five benefits, a significant difference was revealed.

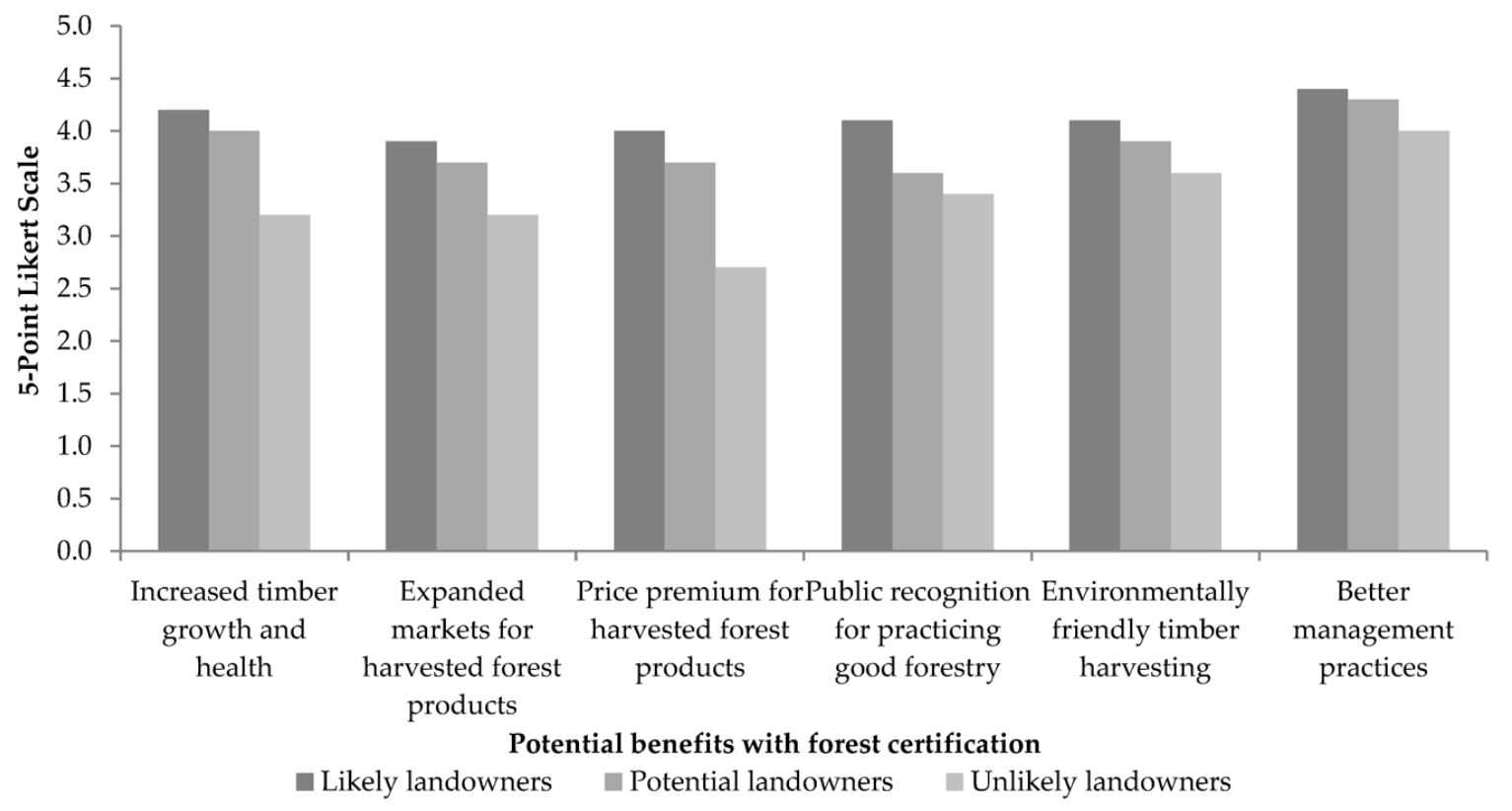

Figure 2. Landowners' perception of potential benefits of forest certification.

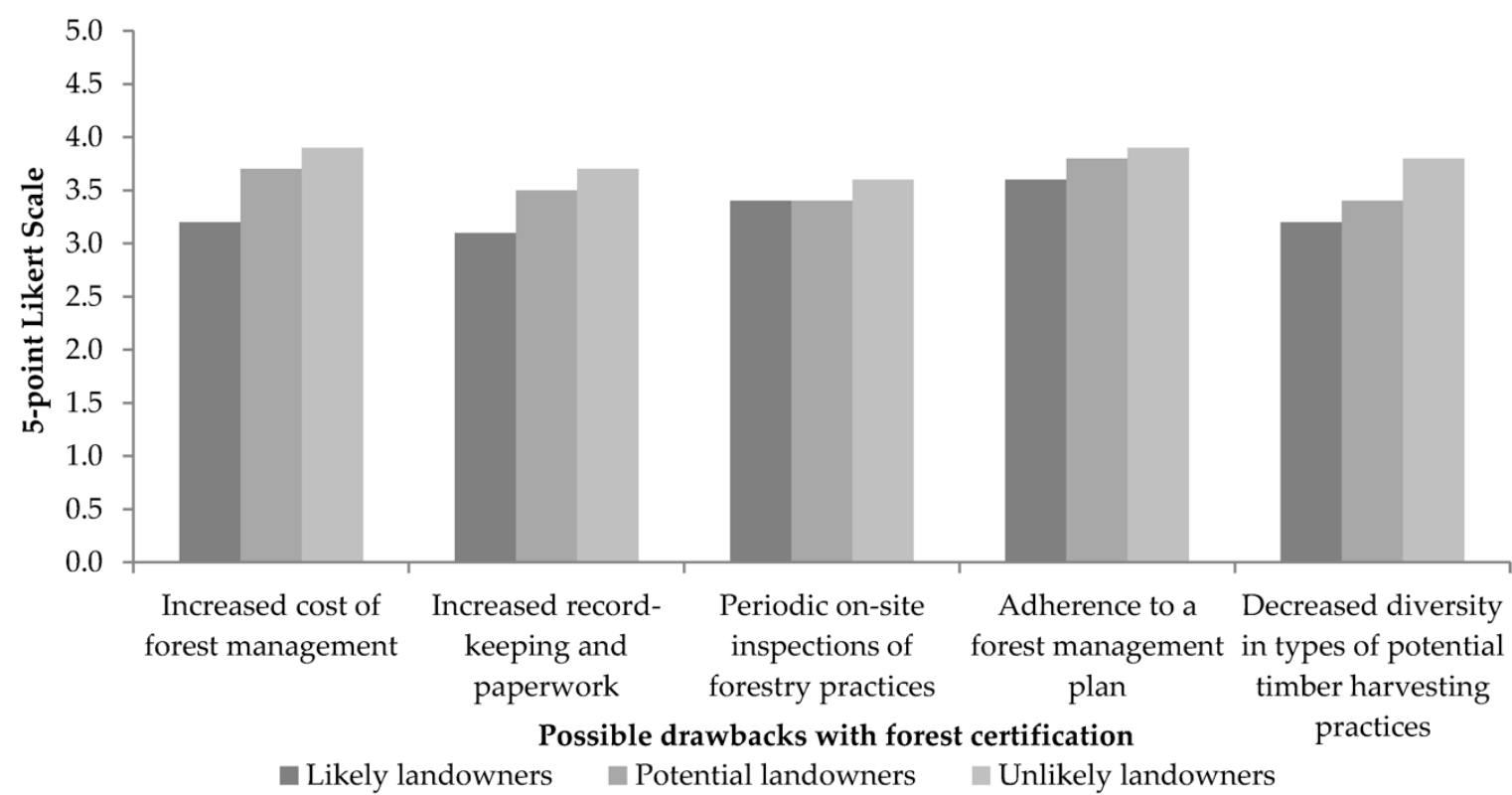

Figure 3. Landowners' perception of potential drawbacks of forest certification.

By contrast, five perceived drawbacks associated with certification programs were: increased forest management cost, more recordkeeping and paperwork, increased periodic on-site inspections, required to comply with a forest management plan, and reduced diversity in timber harvesting. Among obstacles, unlikely landowners had a typical concern with the possible drawbacks of increasing 
management costs and paperwork, on-site inspection, and a decline of timber harvesting diversity (Figure 3). In particular, there was significant difference between likely landowners and potential landowners concerning management costs and increased paperwork/record-keeping (Figure 3). Interestingly, we did not find a significant difference between potential landowners and unlikely landowners for all five possible drawbacks of forest certification (Figure 3). A comparison among three landowners groups suggested no significant difference for on-site inspection and adherence to a management plan-two possible challenges associated with the certification (Figure 3). While bar diagram comparisons suggest more variation among groups concerning perceived benefits than perceived drawbacks of forest certification, these observations could not be conclusive due to a lack of statistical differences.

\section{Discussion}

The landowners in each of the three clusters have different demographics. There was striking similarity among segments in terms of average age. The percentage of female landowners in the cluster of unlikely landowners was significantly higher than the other two clusters, implying that a large percentage of women were unlikely to participate in a certification program. These results contrasted to findings by Tindall et al. [42], which revealed significantly higher engagement of females in environmentally friendly behavior (EFB). In addition, a significant difference was found for both education and income attributes among the three clusters. Likely landowners' educational attainment and household income level were significantly higher than the other two groups. These findings were in line with the results of Ma et al. [37], who found that education was positively related with landowners' willingness to participate in a certification program in the United States. Also, our results implied that occupation was correlated with landowners' interest in adopting forest certification as the majority in the likely landowner cluster were professionals working as a forester, professional manager, or government employee. Previous studies (e.g., $[15,43,44])$ also found that landowner occupation has a significant effect on conservation behavior.

Ownership and forestland characteristics also differed significantly among the three clusters. Ownership size in the clusters of likely and potential landowners was significantly larger than for unlikely landowners, suggesting that small ownership, which may cause a higher per unit cost, can be a concern for landowners to certify their forestland. These results were consistent with the previous findings that passive landowners in the southern United States had the lowest acres of landholding compared to other two groups with active or some interest in wood-based bioenergy [12]. Similarly, our results suggested that landowners with longer tenureship of forestland were more likely to participate in forest certification. In particular, there was a significant difference in tenure between the cluster of likely and unlikely landowners. This observation was consistent with Bensel [34] and Tian et al. [15], who found that tenure was a significant factor influencing landowners' willingness to certify their forestland. Among the three clusters, there was a significant difference in the availability of a management plan, which was positively correlated with their interests in certification. Our results, however, contrasted with previous findings of Kilgore et al. [45], who reported that landowners' participation in a conservation friendly stewardship program was not correlated with whether or not they had a written plan. Our results implied that landowners owning poplar forests might be relatively more willing to certify their forestland. Of note, poplar forest is a common timber production forest in Shandong, China [15,46]. To this end, our observation was consistent with that from Kilgore et al. [1], who found that likely timber certifiers were interested in timber production forests.

Landowners' familiarity degree with forest certification might have an impact on their participation in this program. Likely landowners were more familiar with certification programs than unlikely landowner groups, suggesting that landowners' familiarity with forest certification was positively correlated with rate of participation. This result was in line with Bell et al. [43], Mercker and Hodges [47], and Sun et al. [48], who reported that landowner knowledge on forest certification can positively impact their motivation/willingness to participate. 
Landowners' perceptions of benefits and drawbacks related to forest certification showed significant differences among three segmentations. Likely landowners agreed more on increased timber growth, an expanded market, and price premium than unlikely landowners, suggesting that those three benefits associated with forest certification might have a positive relationship with landowners' willingness to adopt certification. On the contrary, potential and unlikely landowner clusters agreed more on increased management costs and paper work than likely landowners, which implied that those two possible drawbacks might restrict landowners' willingness to participate in certification.

\section{Conclusions and Management Implications}

This study looked at landowners' different attitudes towards forest certification under various program designs and segmented them into three distinct groups. Differences in their socio-demographic characteristics, forestland and ownership characteristics, and familiarity with certification programs, as well as their agreement level on the perceived benefits and drawbacks related to forest certification, have to be taken into account when devising outreach activities. For example, "likely landowners" represented a highly educated and wealthy group with a large ownership size and long tenureship, who seemed to be interested in forest certification programs. However, a considerable percentage of this group did not know the logistic or operational details of certification. Therefore, information on the availability of different volunteer certification programs (e.g., FSC, PEFC, and CFCC) and their enrollment criteria might help this group. Extension professionals should seek highly educated, relatively young male professionals, if they are interested in targeting this audience segment.

On the other hand, since "potential landowners" are skeptical of potential costs associated with forest certification, incentive-based programs such as providing subsidy might help this segment. As our results suggest, Extension professionals are recommended to approach this middle income, relatively educated male audience, should they be interested in targeting "potential landowners". If Extension professionals plan to promote certification in popular forests, they should target "likely or potential landowners".

Finally, since "unlikely landowners" represent landowners in a lower household income bracket, government cost-share assistance might be needed for this group. As their demographics characterize, a significant percentage of landowners in this segment represent females, with a smaller ownership size and shorter tenure, and most of them do not have a university education. Promoters of forest certification in urban areas need to target "unlikely landowners", which will be challenging given their lack of interest in forest certification. Overall, these study results suggested that multifaceted and long-term motivation approaches are needed to encourage more landowners to certify their forestland.

Our study results suggest that females were less interested in forest certification than males. This finding has an important management implication as it relates to commitment to environmentalism in contemporary China from a feminist perspective. Despite being the second largest economy in the world with the highest level of carbon dioxide emissions, there is a lack of scholarship that examines gender differences in environmentally oriented behaviors in China [49]. As such, our findings suggest future research on whether the lack of interest was attributed to a lack of knowledge on forest certification or a lack of concern for environmentalism-a finding that does not resonate with the feminine view on the environment in the global West [49].

A couple of caveats of this research are worth noting. First, while the results in this study provide a guideline for general support of forest certification among diverse landowners, we do not assess whether a landowner will actually choose to participate in forest certification; thus, these results should be interpreted as an indicator of a landowner's intentions to participate given those program requirements. Second, the three landowner groups only represented the landowners in Shandong and could not symbolize the landowners in other provinces. Given the land use and socio-economic diversity in China, a broader study might be needed in the future.

Author Contributions: N.T., O.J., N.P., and F.L. prepared the manuscript and analyzed/interpreted data. N.T. and F.L. implemented the survey. 
Funding: The W. K. McClure Scholarship Program in the Center for International Education at the University of Tennessee for the funding support of data collection in China.

Acknowledgments: We are thankful to the support provided by the Department of Forestry, Wildlife, \& Fisheries at University of Tennessee in completing this study. In addition, we thank the Division of Agricultural Sciences and Natural Resources at Oklahoma State University for publication support.

Conflicts of Interest: The authors declare no conflict of interest.

\section{References}

1. Kilgore, M.A.; Leahy, J.E.; Hibbard, C.M.; Donnay, J.S. Assessing family forestland certification opportunities: A Minnesota case study. J. For. 2007, 105, 27-33.

2. Leslie, A.D. The impacts and mechanics of certification. Int. For. Rev. 2004, 6, 30-39. [CrossRef]

3. Rametsteiner, E.; Simula, M. Forest certification-An instrument to promote sustainable forest management? J. Environ. Manag. 2003, 67, 87-98. [CrossRef]

4. Durst, P.B.; Mckenzie, P.J.; Brown, C.L.; Appanah, S. Challenges facing certification and eco-labelling of forest products in developing countries. Int. For. Rev. 2006, 8, 193-200. [CrossRef]

5. Pattberg, P. Private Institutions and Global Governance; The New Politics of Environmental Sustainability; Edward Elgar: Cheltenham, UK; Northampton, MA, USA, 2007; p. 320.

6. Forest Resources in China. Available online: http://english.forestry.gov.cn/index.php?option=com content\&view=article\&id=2:forest-resources-in-china\&catid=10\&Itemid=134 (accessed on 13 March 2018).

7. Programme for the Endorsement of Forest Certification Schemes (PEFC). China's National Forest Certification System Achieves PEFC Endorsement. Available online: http:/ / pefc.org/news-a-media/general-sfm-news/ 1459-china-s-national-forest-certification-system-achieves-pefc-endorsement (accessed on 14 January 2017).

8. Shapiro, J. Mao's War against Nature: Politics and the Environment in Revolutionary China; Cambridge University Press: Cambridge, UK; New York, NY, USA, 2001.

9. Liu, J. China's Road to Sustainability. Science 2010, 328, 50. [CrossRef] [PubMed]

10. Ma, T. Interconnected Forests: Global and Domestic Impacts of China's Forestry Conservation; A China Environmental Health Project Research Brief; Wilson Center China Environment Forum: Washington, DC, USA, 2008; p. 6.

11. Sun, X.; Candy, K.; Liu, L. China's Logging Ban in Natural Forests: Impacts of Extended Policy at Home and Abroad; Forests Trends Information Brief; Forest Trends: Washington, DC, USA, 2017; p. 8.

12. Joshi, O.; Mehmood, S.R. Segmenting southern nonindustrial private forest landowners on the basis of their management objectives and motivations for wood-based bioenergy. South. J. Appl. For. 2011, 35, 87-92.

13. Thompson, D.W.; Hansen, E.N. Factors affecting the attitudes of nonindustrial private forest landowners regarding carbon sequestration and trading. J. For. 2012, 110, 129-137. [CrossRef]

14. Tian, N.; Poudyal, N.C.; Hodges, D.G.; Young, T.M.; Hoyt, K.P. Understanding the Factors Influencing Nonindustrial Private Forest Landowner Interest in Supplying Ecosystem Services in Cumberland Plateau, Tennessee. Forests 2015, 6, 3985-4000. [CrossRef]

15. Tian, N.; Poudyal, N.C.; Lu, F. Understanding Landowners' interest and willingness to participate in forest certification program in China. Land Use Policy 2018, 71, 271-280. [CrossRef]

16. Kurtz, W.B.; Lewis, B.J. Decision-making framework for nonindustrial private forest owners: An application in the Missouri Ozarks. J. For. 1981, 79, 285-288.

17. Kuuluvainen, J.; Karpppinen, H.; Ovaskainen, V. Landowner objectives and nonindustrial private timber supply. For. Sci. 1996, 42, 300-309.

18. Kline, J.D.; Alig, R.J.; Johnson, R.L. Fostering the production of nontimber services amongst forest owners with heterogeneous objectives. For. Sci. 2000, 46, 302-311.

19. Kluender, R.A.; Walkingstick, T.L. Rethinking how nonindustrial landowners view their lands. South. J. Appl. For. 2000, 24, 150-158.

20. Boon, T.E.; Meilby, H.; Thorsen, B.J. An empirically based typology of private forest owners in Denmark: Improving communication between authorities and owners. Scand. J. For. Res. 2004, 19, 45-55. [CrossRef]

21. Kendra, A.; Hull, R.B. Motivations and behaviors of new forest owners in Virginia. For. Sci. 2005, 51, $142-154$.

22. Majumdar, I.; Lawrence, T.; Butler, B. Characterizing family forest owners: A cluster analysis approach. For. Sci. 2008, 54, 176-184. 
23. Hujala, T.; Kurttila, M.; Karppinen, H. Cross-evaluation of two forest owner typologies: How do motives of ownership and needs of communication interact? In Small Scale Forestry in a Changing World: Opportunities and Challenges and the Role of Extension and Technology Transfer, Proceedings of the IUFRO Conference, Bled, Slovenia, 6-12 June 2010; Medved, M., Ed.; CD-ROM; Slovenian Forest Institute \& Slovenia Forest Service: Ljubljana, Slovenia, 2010; pp. 320-330.

24. Surendra, G.C.; Mehmoodt, S.; Schelhas, J. Segmenting Landowners Based on Their Information-Seeking Behavior: A Look at Landowner Education on the Red Oak Borer. J. For. 2009, 107, 313-319.

25. Salmon, O.; Brunson, M.; Kuhns, M. Benefit-Based Audience Segmentation: A Tool for Identifying Nonindustrial Private Forest (NIPF) Owner Education Needs. J. For. 2006, 104, 419-425.

26. Butler, B.J.; Tyrrell, M.; Feinberg, G.; VanManen, S.; Wiseman, L.; Wallinger, S. Understanding and Reaching Family Forest Owners: Lessons from Social Marketing Research. J. For. 2007, 105, 348-357.

27. Herbohn, J.L.; Emtage, N.F.; Harrison, S.R.; Smorfitt, D.B. Attitudes of landholders to farm forestry in tropical Eastern Australia. Aust. For. 2005, 68, 50-58. [CrossRef]

28. Hujala, T.; Tikkanen, J.; Hänninen, H.; Virkkula, O. Family forest owners' perception of decision support. Scand. J. For. Res. 2009, 24, 448-460. [CrossRef]

29. World Wildlife Fund European Forest Programme. The Effects of FSC Certification in Estonia, Germany, Latvia, Russia, Sweden and the UK; Summary Report \& Country Reports; World Wildlife Fund European Forest Programme: Brussels, Belgium, 2005.

30. Oy, S.I. Effectiveness and Efficiency of FSC and PEFC Forest Certification on Pilot Areas in Nordic Countries; Final Report; Federation of Nordic Forest Owners' Organizations: Helsinki, Finland, 2005.

31. Rickenbach, M.; Overdevest, C. More than markets: Assessing Forest Stewardship Council (FSC) certification as a policy tool. J. For. 2006, 104, 143-147.

32. Busby, G.M.; Montgomery, C.A.; Latta, G.S. The opportunity cost of forest certification on private land in Western Oregon. West. J. Appl. For. 2007, 22, 55-60.

33. Nussbaum, R.; Simula, M. The Forest Certification Handbook, 2nd ed.; Earthscan: London, UK, 2005; p. 300.

34. Bensel, T. Promoting certified sustainable forestry on private woodlots in north-western Pennsylvania: Challenges and opportunities. Local Environ. 2001, 6, 257-278. [CrossRef]

35. Perera, P.; Vlosky, R.P.; Hughes, G.; Dunn, M.A. What do Louisiana and Mississippi nonindustrial private forest landowners think about forest certification? South. J. Appl. For. 2007, 31, 170-178.

36. Cubbage, F.; Moore, S.; Henderson, T.; Araujo, M.F.C. Costs and Benefits of Forest Certification in the Americas. Natural Resources: Management, Economic Development and Protection; Nova Publishers: Hauppauge, NY, USA, 2009; Chapter 5; pp. 155-183.

37. Ma, Z.; Butler, B.J.; Kittredge, D.B.; Catanzaro, P. Factors associated with landowner involvement in forest conservation programs in the U.S.: Implications for policy design and outreach. Land Use Policy 2012, 29, 53-61. [CrossRef]

38. Macqueen, J.B. Some methods for classification and analysis of multivariate observations. In Proceedings of the 5th Berkeley Symposium on Mathematical Statistics and Probability, Berkeley, CA, USA, 21 June-18 July 1965; University of California Press: Berkeley, CA, USA, 1967; pp. 281-287.

39. Silver, M. Scales of measurement and cluster analysis: An application concerning market segments in the babyfood market. Statistician 1995, 44, 101-112. [CrossRef]

40. Chiu, T.; Fang, D.; Chen, J.; Wang, Y.; Jeris, C. A robust and scalable clustering algorithm for mixed type attributes in large database environment. In Proceedings of the International Conference on Knowledge Discovery and Data Mining, San Francisco, CA, USA, 26-29 August 2001; pp. 263-268. Available online: https: / / dl.acm.org/citation.cfm?id=502549 (accessed on 13 March 2018).

41. Hair, J.F.; Black, B.; Babin, B.; Anderson, R.E.; Tatham, R.L. Multivariate Data Analysis, 6th ed.; Prentice Hall, Inc.: Upper Saddle River, NJ, USA, 2006; 899p.

42. Tindall, D.B.; Davies, S.; Mauboules, C. Activism and conservation behavior in an environmental movement: The contradictory effects of gender. Soc. Nat. Resour. 2003, 16, 909-932. [CrossRef]

43. Bell, C.D.; Roberts, R.K.; English, B.C.; Park, W.M. A logit analysis of participation in Tennessee's Forest Stewardship Program. J. Agric. Appl. Econ. 1994, 26, 463-472. [CrossRef]

44. Nagubadi, V.; McNamara, K.T.; Hoover, W.L.; Mills, W.L. Program participation behavior of nonindustrial forest landowners: A probit analysis. J. Agric. Appl. Econ. 1996, 28, 323-336. [CrossRef] 
45. Kilgore, M.A.; Taff, S.S.; Schertz, J. Family Forest Stewardship: Do Owners Need a Financial Incentive? J. For. 2008, 106, 357-362.

46. Tian, N.; Lu, F. Adaptive management decision of agroforestry under timber price risk. J. For. Econ. 2013, 19, 162-173.

47. Mercker, D.; Hodges, D.G. Modeling landowner behavior regarding forest certification. In Proceedings of the 16th Central Hardwood Forest Conference, West Lafayette, IN, USA, 8-10 April 2008.

48. Sun, X.; Sun, C.; Munn, I.A.; Hussain, A. Knowledge of public assistance programs and application behavior of nonindustrial private forest landowners: A two-step sample selection model. J. For. Econ. 2009, 15, 187-204.

49. Xiao, C.; Hong, D. Gender differences in environmental behaviors in China. Popul. Environ. 2010, 32, 88-104. [CrossRef]

(C) 2018 by the authors. Licensee MDPI, Basel, Switzerland. This article is an open access article distributed under the terms and conditions of the Creative Commons Attribution (CC BY) license (http://creativecommons.org/licenses/by/4.0/). 